\title{
Report on an optics outreach program in Montréal
}

\section{François Busque, Yasaman Soudagar}

François Busque, Yasaman Soudagar, "Report on an optics outreach program in Montréal," Proc. SPIE 9665, Tenth International Topical Meeting on Education and Training in Optics and Photonics, 96650G (3 June 2007); doi: $10.1117 / 12.2207488$

SPIE Event: Tenth International Topical Meeting on Education and Training in Optics and Photonics, 2007, Ottawa, Ontario, Canada 


\title{
Report on an Optics Outreach Program in Montréal
}

\author{
François Busque and Yasaman Soudagar \\ École Polytechnique de Montréal, Department of Engineering Physics, \\ PO box 6079, station Centre-ville, Montreal, Quebec, H3C 3A7, Canada \\ (514) 340-4711 ext 4717 \\ francois.busque@polymtl.ca
}

\begin{abstract}
In accordance with its mission, the Student Chapter of the Optical Society of America (OSA) in École Polytechnique de Montréal organises numerous outreach activities to trigger the interest of students 6-17 years of age in optics. In the last two years, these workshops have attracted over 450 students.

(C) 2007 Optical Society of America
\end{abstract}

OCIS codes: (000.2060) Education, (000.1200) Announcements, awards, news, and organizational activities

\section{Chapter Outreach Activities Background}

One part of Optical Society of America's (OSA) mission is to disseminate information about optics and photonics worldwide. As a way to reach this goal, it creates and finances regional student chapters who would do educational outreach. The OSA Student Chapter of École Polytechnique de Montréal has been founded in 2003 with optics education in mind as one of its main goals. In the last years, we decided to focus our activities on outreaching young people in order to encourage them to pursue their studies in the field of optics. We strongly believe in the importance of this mission because it attracts young students to the fascinating field of optics and hence we participate in forming the next generation of engineers and scientists in our domain, and because, at the same time, it increases the awareness of decision makers of tomorrow about the importance of scientific work. We started our mission by demonstrating exciting optics phenomena to students in university's open houses and in events we organised at the university. Our activities were very much appreciated by young people and demands for demonstrations increased. Meanwhile, we realised that hands-on activities would be even more captivating than demonstrations and decided to duplicate the setups to enable student direct participation in the activities. Hence, our outreach programs have developed into hands-on activities designed for teams of two and are very successful. These activities effectively captivate younger kids and teach wave properties of light, properties of waveguides, electronic circuits and optical signal modulation with their applications in telecommunication to middle and high school students. In this paper we describe six of our most successful activities.

\section{Description of the Activities}

In order to effectively reach a significant number of students, the activities organised are often integrated into other events such as university open houses, annual science fairs and "Girls and Science" programs [1]. It allows us to benefit from the organisation, publicity and infrastructure of the event such that we can concentrate on the preparation of the activity itself. To reach even more students, the Chapter also gives hands-on courses to groups of teachers so they can spread the knowledge in their schools. The Chapter has also published an optics teaching

Tenth International Topical Meeting on Education and Training in Optics and Photonics, edited by Marc Nantel, Proc. of SPIE Vol. 9665, 96650G · @ 2007 SPIE, OSA, IEEE, ICO doi: $10.1117 / 12.2207488$ 
manual that is distributed to some high-schools [2] and is available free of charge to all teachers in Québec's province (Canada). Table 1 summarises the activities we have organised thus far and gives some information about the time and money required to organise these activities. Details about each activity follow.

Table 1: Summary of activities and heritage on preparation time and cost of the activities

\begin{tabular}{|c|c|c|c|c|c|c|}
\hline Activity & $\begin{array}{c}\text { Gelatine } \\
\text { waveguide } \\
\text { workshop }\end{array}$ & $\begin{array}{l}\text { Telecommunication } \\
\text { hands-on activity }\end{array}$ & $\begin{array}{c}\text { Extreme } \\
\text { Microwave } \\
\text { presentation }\end{array}$ & $\begin{array}{l}\text { Liquid } \\
\text { crystals } \\
\text { activity }\end{array}$ & $\begin{array}{c}\text { Special } \\
\text { hands-on } \\
\text { activity for } \\
\text { teachers } \\
\end{array}$ & $\begin{array}{c}\text { Optics } \\
\text { outreach } \\
\text { activity guide }\end{array}$ \\
\hline $\begin{array}{l}\text { Targeted } \\
\text { audience }\end{array}$ & $\begin{array}{l}\text { Middle and } \\
\text { high school } \\
\text { students }\end{array}$ & $\begin{array}{l}\text { Middle and high school } \\
\text { students }\end{array}$ & $\begin{array}{l}\text { Students and } \\
\text { parents }\end{array}$ & $\begin{array}{l}\text { High school } \\
\text { teachers }\end{array}$ & $\begin{array}{l}\text { High school } \\
\text { teachers }\end{array}$ & $\begin{array}{l}\text { High school } \\
\text { teachers }\end{array}$ \\
\hline $\begin{array}{l}\text { Number of } \\
\text { participants in } \\
\text { each activity } \\
\text { session }\end{array}$ & 10 to 40 & 10 to 40 & 80 to 250 & 40 & 40 & - \\
\hline Event & $\begin{array}{l}\text { Open house, } \\
\text { "Girls and } \\
\text { Science" }\end{array}$ & Open house & $\begin{array}{l}\text { Open house, } \\
\text { autonomous } \\
\text { activity }\end{array}$ & $\begin{array}{l}\text { "Girls and } \\
\text { Science" }\end{array}$ & $\begin{array}{l}\text { "Girls and } \\
\text { Science" }\end{array}$ & - \\
\hline $\begin{array}{l}\text { Preparation } \\
\text { time to build } \\
\text { the kit }\end{array}$ & 3 hours & 40 hours & 10 hours & 3 hours & 10 hours & 80 hours \\
\hline $\begin{array}{l}\text { Preparation } \\
\text { time for each } \\
\text { session }\end{array}$ & 1 hour & 1 hour & 1 hour & - & 2 hours & - \\
\hline $\begin{array}{l}\text { Minimum } \\
\text { activity length }\end{array}$ & $30 \mathrm{~min}$ & $30 \mathrm{~min}$ & $60 \mathrm{~min}$ & $30 \mathrm{~min}$ & 1 hour & - \\
\hline $\begin{array}{l}\text { Cost (\$US) to } \\
\text { build the kits }\end{array}$ & 50 & 485 & 50 & - & - & - \\
\hline $\begin{array}{l}\text { Cost of each } \\
\text { session for } 10 \\
\text { teams ( SUS ) }\end{array}$ & 5 & 10 & 10 & 10 & 25 & - \\
\hline Note & \multicolumn{2}{|c|}{$\begin{array}{l}\text { Gelatine and telecommunication activities } \\
\text { are often joined into a single activity }\end{array}$} & $\begin{array}{c}\text { Setup cost } \\
\text { does not } \\
\text { include the } \\
\text { microwave } \\
\text { oven }\end{array}$ & $\begin{array}{l}\text { Our initial } \\
\text { setup is kindly } \\
\text { provided by } \\
\text { Dr. Jacobs [3] }\end{array}$ & $\begin{array}{c}\text { We used } \\
\text { material from } \\
\text { our other } \\
\text { activities }\end{array}$ & $\begin{array}{c}\text { Financed and } \\
\text { edited by a } \\
\text { non-profit } \\
\text { organisation }\end{array}$ \\
\hline
\end{tabular}

\section{a) Gelatine Waveguide Workshop}

The gelatine workshop is a hands-on activity where transparent gelatine is used to create waveguides and a laser pointer is used as a source to teach the principles of total internal reflection, light propagation in bent waveguides and optical couplers to middle and high school students.

We normally arrange the seats in the room to facilitate having 10 teams of two or three students. Usually three Chapter members lead this activity. One member first introduces the activity with a short presentation on the general concepts behind waveguides, including total internal reflection and its role in transferring light into media such as optical fibres. Each team receives a piece of gelatine, a ruler, a knife, a plastic tablemat and napkins, plus a regular red laser pointer. They are led to observe the total internal reflection of red laser light in straight and bent gelatine slabs, and to create different optical devices such as waveguides, power splitters and couplers while the presenter explains how light travels in a bent fibre and optical couplers. During this time, the two other members answer questions and assist the teams by making sure they follow the required steps

To prepare the gelatine (Table 2) before the activity, 6 pounds of unflavoured cooking Knox ${ }^{\mathrm{TM}}$ gelatine [4] is mixed with 1 litre of warm water. Then, the mixture is poured into a plate to form a $2-\mathrm{cm}$ thick gelatine slab and chilled until set before being cut into $6 \mathrm{~cm} \times 20 \mathrm{~cm}$ pieces to be used to create the waveguides. 
Table 2: Gelatine waveguide workshop material required for ten teams of two or three students

\begin{tabular}{|l|l|l|}
\hline Quantity & \multicolumn{1}{|c|}{ Material } & \multicolumn{1}{c|}{$\begin{array}{c}\text { Approximate Total Cost } \\
\text { [\$US] }\end{array}$} \\
\hline $\begin{array}{l}12 \\
\text { pouches }\end{array}$ & Knox gelatine & 3 \\
\hline 10 & Laser pointers & 10 \\
\hline 10 & Rulers & 10 \\
\hline 10 & Cutters & 10 \\
\hline 10 & Tablemats & 10 \\
\hline 2 & $\begin{array}{l}\text { Container to prepare the } \\
\text { gelatine }\end{array}$ & $\begin{array}{l}\text { Borrowed from Chapter } \\
\text { members }\end{array}$ \\
\hline 1 & Pack of wet napkins & 3 \\
\hline
\end{tabular}

The use of gelatine and red laser light provides a vivid visual reference to students for some of the most important and fundamental applications of waveguides, which are the basis of telecommunication systems. The pedagogic impact of the image of red laser light internally reflecting off the walls of gelatine waveguide as well as the beam of light being divided into two paths and propagating in different branches in a gelatine coupler on the students' long-term learning cannot be overstated.

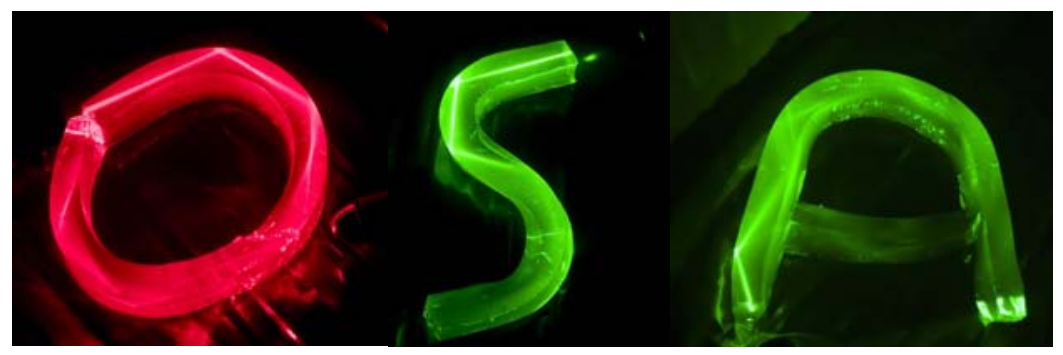

Figure 1: Total internal reflection occurring in gelatine waveguides

\section{b) Telecommunication Hands-on Activity}

The telecommunication hands-on activity works as the complement of the gelatine waveguide activity and gives a broad view of telecommunication systems to students. Hence the students are in 10 teams of two or three and 3 chapter members lead the activity. Before starting the practical part, we carry on a short brainstorming session on the meaning of telecommunication, and we give a theoretical presentation on the extent of the global telecommunication system and its usage in daily life such as telephone conversations.

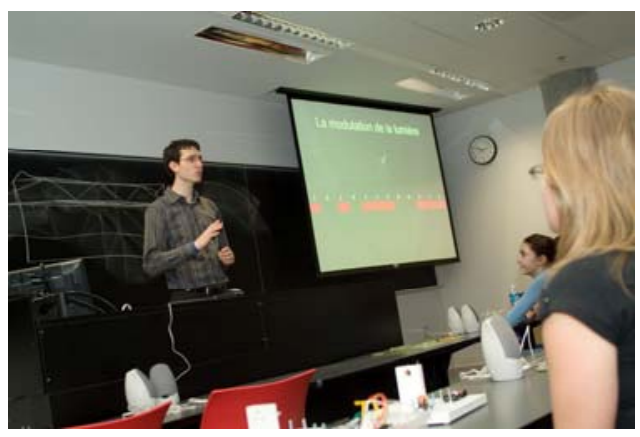

Figure 2: Teaching transmission of data by optical pulses 
Each group receives a telecom kit (Figure 3 and Table 3) designed and built by our Student Chapter to demonstrate the implementation of a circuit transmitting sound through an optical signal. These kits are designed with an emphasis on ease of use for participants, both in terms of understanding the electric circuits involved and practical method of connecting the components.

The kit consists of two boards, one for the emitter circuit and one for the receiver circuit. On the emitter side, the sound signal to be emitted is converted to an optical signal through a laser pointer. The optical signal is then transmitted either through free space or through a gelatine waveguide to the receiver side. The receiver side uses a photo-cell to convert the optical signal back to an electric signal to feed the speaker load. All components of the circuits are fixed on the kit boards with long screws used as connectors. Participants can easily connect the appropriate screws using wires with alligator clips to close the circuits. For each setup, an AM/FM radio or an amplified microphone bought in a dollar store is used as the input sound source. Alternatively, the participants may use their own MP3 player. The output is a pair of standard computer speakers.

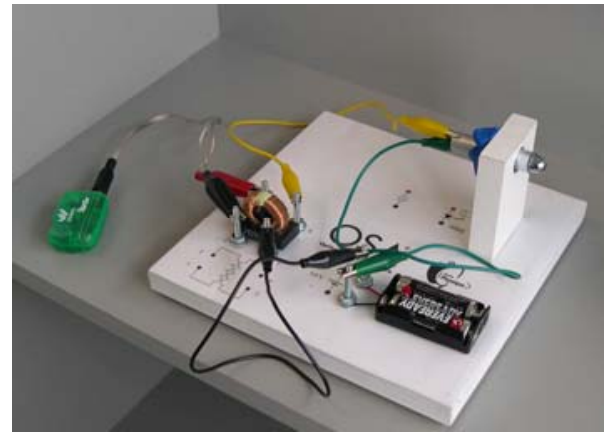

Laser pointer

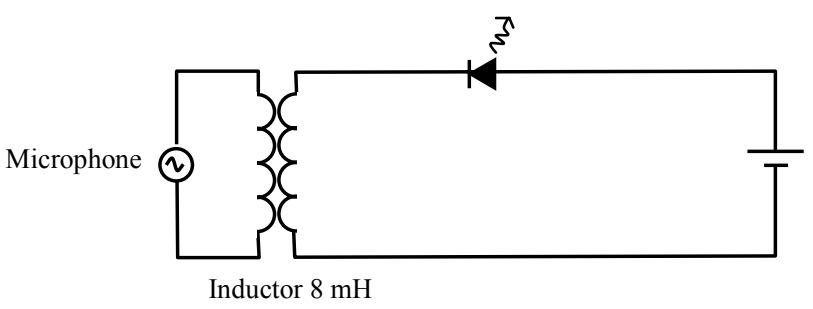

(a

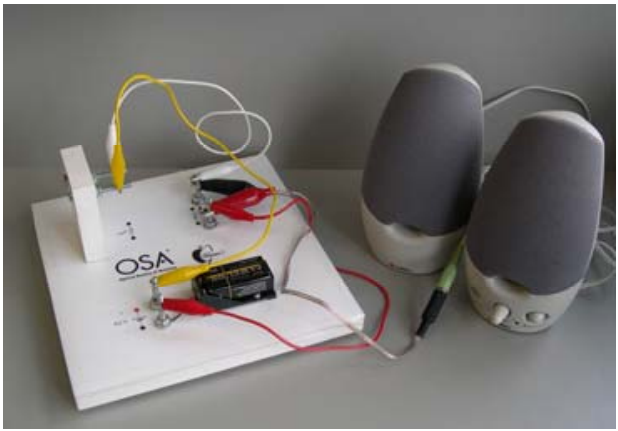

Photocell $3 \mathrm{k} \Omega$ - $11 \mathrm{k} \Omega$

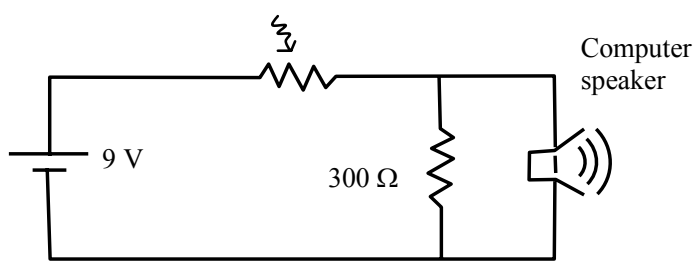

(b)

Figure 3: Emitter (a) and receiver (b) circuits mounted on individual boards. 
Table 3: Telecom kit material required for ten teams

\begin{tabular}{|c|c|c|c|}
\hline Quantity & $\begin{array}{l}\text { Part Number (Digi- } \\
\text { Key Corporation) }\end{array}$ & Material & $\begin{array}{l}\text { Approximate } \\
\text { Total Cost [\$US] }\end{array}$ \\
\hline 20 & - & 8"x 8" wooden boards & 150 \\
\hline 10 & - & Amplified microphones & 10 \\
\hline 10 & - & $\mathrm{AM} / \mathrm{FM}$ radios & 10 \\
\hline 10 & - & Computer speakers & 100 \\
\hline 1 pack & - & Screws & 5 \\
\hline 1 pack & - & Nuts & 5 \\
\hline 1 pack & - & Washers & 5 \\
\hline 10 & PDV-P8001-ND & Photocells $3 \mathrm{k} \Omega-11 \mathrm{k} \Omega$ ohm, $5.10 \mathrm{~mm}$ & 22 \\
\hline 10 & OD301J-ND & Resistors, $300 \Omega, 0.25 \mathrm{~W}$ & 4 \\
\hline 10 & BH9V-W-ND & $9 \mathrm{~V}$ battery holders & 8 \\
\hline 10 & $2463 \mathrm{~K}-\mathrm{ND}$ & 2 AA battery holders, 6 " lead & \\
\hline 10 & 237-1232-ND & Inductors, $8 \mathrm{mH}$ & 40 \\
\hline 10 & GC396-ND & Wire test leads, 27 awg, 15" & 58 \\
\hline 20 & CP-2410-ND & Alligator clips, $44 \mathrm{~mm}$, black & 9 \\
\hline 25 & CP-2411-ND & Alligator clips, $44 \mathrm{~mm}$, red & 11 \\
\hline 1 & W200-100-ND & Speaker wire, 22 awg, 100' & 7 \\
\hline 10 & CP-3506-ND & $3.5 \mathrm{~mm}$ connectors, female, mono & 11 \\
\hline 20 & CP-3501-ND & $3.5 \mathrm{~mm}$ connectors, male power plug & 13 \\
\hline 10 & - & Laser pointers & 10 \\
\hline
\end{tabular}

The telecommunication hands-on activity proves to the students that learning optics and technology is not beyond their reach and capability. During this activity, in addition to learning the principles of telecommunication and the concept of signal conversion from sound to electric to optical and vice versa, students obtain hands-on experience in mounting complete electric circuits, aligning laser light so that it reaches its destination. Other than the excitement and satisfaction of learning about one of the most important contemporary technologies, finishing the task provides them with a sense of achievement and increases their confidence in their ability to learn and do science.

\section{c) Extreme Microwave Presentation}

The Extreme Microwave presentation showcases amazing optical phenomena triggered by the common kitchen microwave oven (Table 4). During the microwave shows, the basic principles of microwave ovens are first explained to participants. Then, we describe the optical phenomena that underlie the creation of electric-arcs in the oven using a piece of carrot, the generation of sparks using steel wool, the creation of a plasma with a common wax candle, and the creation of luminous worms moving in a fractal pattern for example on a compact disk (CD). To accommodate a large audience with a single oven, a webcam is used to project the live image of the oven interior on a giant screen. Over the years, we found that best results are achieved with ovens that do not use a wave stirrer fan and hence create intense localised hotspots due to constructive interference. These are usually the ones that are equipped with a turntable inside. In order to reach the optimum result, the turning plate should be removed and the experimental object should be placed in the oven where constructive interference arises.

(a)

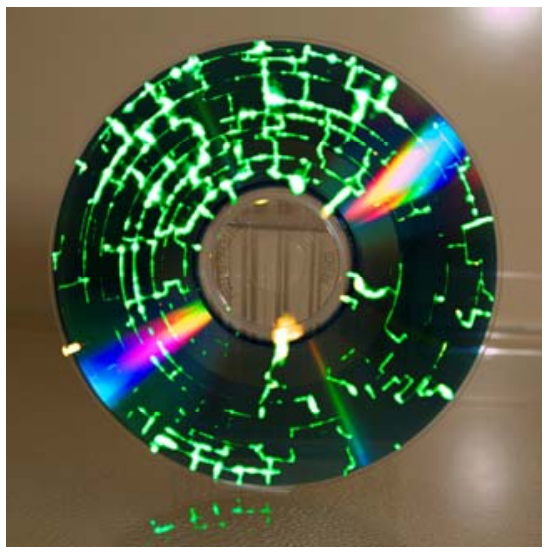

(b)

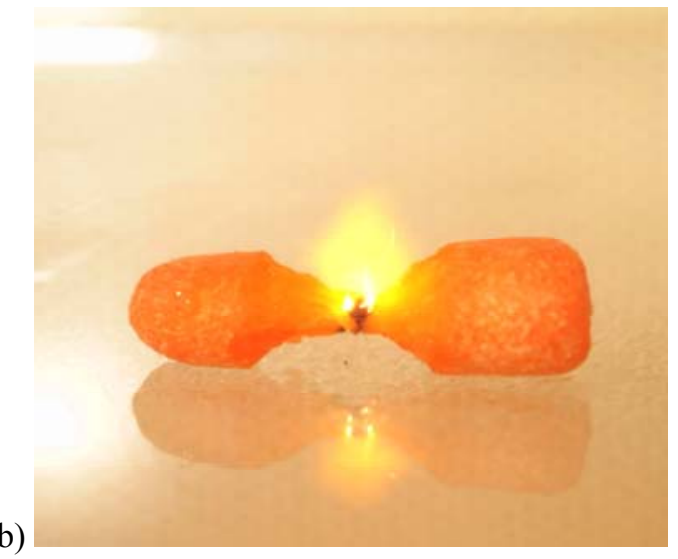

Figure 4: Optical phenomenon observed with a CD (a) and a carrot (b) in a common kitchen microwave oven 
Table 4: Examples of objects experimented during Extreme Microwave presentations

\begin{tabular}{|l|l|l|}
\hline Object & Effect & Note \\
\hline CD and DVD & $\begin{array}{l}\text { Creation of fine green luminous } \\
\text { worms moving on the disk surface }\end{array}$ & $\begin{array}{l}\text { CD-RW, CD-R and CDs that are volume printed } \\
\text { like the ones we get when we buy software give } \\
\text { different results. }\end{array}$ \\
\hline $\begin{array}{l}\text { Carrot and } \\
\text { grape }\end{array}$ & $\begin{array}{l}\text { Creation of plasma at the junction } \\
\text { between the two halves. }\end{array}$ & $\begin{array}{l}\text { Carrots must be cut with a tapered center (see } \\
\text { figure 4-b). The grapes must be almost } \\
\text { completely cut in halves, keeping the skin to } \\
\text { connect the two halves. }\end{array}$ \\
\hline $\begin{array}{l}\text { Incandescent } \\
\text { light bulb }\end{array}$ & $\begin{array}{l}\text { Light bulb's filament will light and } \\
\text { stable plasma can be created in the } \\
\text { bulb. }\end{array}$ & $\begin{array}{l}\text { Clear light bulbs are preferable. Letting the } \\
\text { plasma run in the bulb might melt the bulb and } \\
\text { create a nice shape after the glass blows up. }\end{array}$ \\
\hline $\begin{array}{l}\text { Fluorescent } \\
\text { tube }\end{array}$ & Tube will light. & Steel wool will catch fire. \\
\hline Steal wool & $\begin{array}{l}\text { A small quantity of steel wool should be used } \\
\text { since it creates a lot of smoke and might be } \\
\text { difficult to extinguish. }\end{array}$ \\
\hline Lit candle & $\begin{array}{l}\text { Creation of a plasma ball floating in } \\
\text { the microwave. }\end{array}$ & $\begin{array}{l}\text { It is possible to stabilise the plasma ball if the } \\
\text { candle is put under a large glass bowl. }\end{array}$ \\
\hline
\end{tabular}

The microwave demonstrations are very effective in attracting the interest of a very large public during events such as university open houses. The activity is such a resounding success every time that a 250 -seat university amphitheatre is filled easily. Kids, teenagers and adults of every age are eager to see the spectacular demonstrations which are heavily publicised. Most adults and people with a scientific background are fond of hearing about plasmas, energy conversion from microwave energy to visible light, and electric discharges on CDs. For their part, kids are principally interested in the spectacular results themselves.

\section{d) Liquid Crystals Activity}

During the fifth annual OSA Student Chapter leadership meeting held on October 2006, Dr. Stephen D. Jacobs and his group from University of Rochester [3] introduced a very intriguing educational kit on liquid crystals. Using this kit, the optical properties of liquid crystals and their dependence on temperature is taught to students through the making of mood patches that change their color according to body temperature. One can then point out the many applications of liquid crystals to today's technology.

Thus far, we have trained a group of teachers to use this liquid crystal kit. Two members were needed for this activity. One member helped each team with the practical section, while the other explained the theoretical presentation. In the workshop, we explained the necessary scientific background then helped them go through the kit once and make mood patches themselves. To provide better support for teachers to give the activity in their classrooms, we supplied them with detailed instructions and information provided by Dr. Jacobs.

\section{e) Special Hands-on Activity for Teachers}

We have optimised our strategy to reach more students using the means available to us by targeting teachers. In fact, we decided to train high school teachers to use our setups so they can directly use our outreach activities in their own classes. Recently, we gave our first demonstration to a group of 40 teachers in the framework of a "Girls and Science" event [1] in Montreal. Teachers received training to prepare the material to perform the gelatine and telecommunication activities as well as the liquid crystal experiment.

In order to help teachers reproduce the activities in their classes, the Chapter has offered to provide them with detailed instructions on how to build the telecommunication kits and has offered to go once to their classroom and help them with the activity. The Chapter also lends all the material and setups to teachers who request it, free of charge.

The teachers who attended the workshop obtained a high level of comfort with the scientific content and felt quite confident about performing the activities in their classrooms. They showed a lot of interest in our kits. Although our Chapter has offered to lend the kits to teachers, no teacher has made a request yet, but they have rather requested detailed instructions to build their own setups. We hope the full support and all the information we have provided for teachers completely enables them to carry on the activities in their classrooms. 


\section{f) Optics Outreach Activity Guide}

Another way we found to reach high school teachers was to publish a manual on optics outreach activities. We wrote a guide [2] that provides detailed guidelines about how to give interesting and engaging hands-on activities with light. It addresses science teachers who already have knowledge of refraction but are not comfortable with explaining guided optics concepts. The manual first explains the fundamentals of fibre optics and gives the scope of the activity. Then, it describes three activity modules: refraction of light, total internal reflection and waveguides. The activities use fish tanks, gelatine and laser pointers to demonstrate the concepts. For each activity, the guide gives the list of material, detailed instructions to give the activity and the explanations to be given to students. At the end of the guide, wrap-up questions and discussion topics are suggested. Our guide will be distributed in Quebec province (Canada) high-schools by our editor who has kindly waived all fees for this publication. The editor, CHAPOP, is a non-profit organisation whose mission is to support young people through the development of individual and social skills. Their goals achieved in publishing our guide are to heighten teenagers' awareness in choosing a career in sciences and technologies and reinforce teenagers' motivation and determination to study.

\section{Results and conclusion}

The participants in our activities give us excellent feedback. We distributed a survey to measure their satisfaction in some open houses. The attendants were mainly composed of high school students and their parents. $97 \%$ of them have rated our outreach activities 'very' or 'extremely' interesting, while finding the workshops to be captivating, complete and instructive. Some even declared that they now seriously consider pursuing studies in optics.

Up to now, we have given our demonstrations and hands-on activities to approximately 450 students from grade school to university level. The described activities have fulfilled the Chapter's objectives by providing an opportunity for young students to interact with scientists and presenting optics concepts which may not be part of their regular school curriculum. Participants' testimonials lead us to believe that we have left participants with an attractive image of the field of optics.

\section{Acknowledgement}

The authors thank all the members of École Polytechnique OSA Student Chapter for their hard work. They also sincerely appreciate the teaching material and the liquid crystals kits that were courteously provided to the Chapter by Dr. Stephen D. Jacobs. Student chapter's activities are financially supported by OSA Student Chapter activity grants and by the Engineering Physics Department of École Polytechnique de Montréal.

\section{References}

[1] See http://www.lesfillesetlessciences.ca/

[2] M. Aubé and F. Busque, "La fibre optique : l'autoroute de la lumière", Chantier d'apprentissage optimal - CHAPOP, Montreal, 2007, 22 p. The manual can be obtained by writing to the editor at info@chapop.ca.

[3] The instructions to find material are distributed free of charge by Dr. Stephen D. Jacobs (sjac@lle.rochester.edu).

[4] Michael E. Knotts, “Optic Fun With Gelatin”, Optics and Photonics News, (50), April, 1997 